\title{
Water-safety strategies and local-scale spatial quality
}

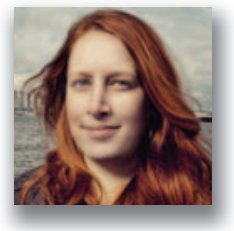

Anne Loes Nillesen MSc

Lecturer and researcher, Department of Urbanism, Faculty of Architecture,

Delft University of Technology, The Netherlands

Delta regions throughout the world are subject to increasing flood risks. For protection, regional water-safety strategies are being developed. Local-scale spatial qualities should be included in their evaluation. An experimental methodology has been developed for this purpose. This paper concentrates on water safety in The Netherlands. The Deltaprogram aims to ensure the country's water safety until 2100. A sub-programme, Rhine Estuary-Drechtsteden, defines scenarios for water-safety interventions that use combinations of permanent or flexible, opening or closing of connections between the Dutch delta, North Sea and river systems. Cross-sections show water levels throughout the urbanised Rhine Estuary region, based on forecasts for each of the scenarios, and local-scale interventions, such as dykes or flood barriers. The interventions are rated using existing and new criteria for the evaluation of spatial quality. Dominant criteria for each area have been used to define design criteria. The choice of a solution on a regional scale is shown to have a significant impact on the spatial quality on a local scale. In particular, water-safety interventions that result in extreme water levels have a negative impact. The methodology is suitable for estimating the impact of a regional water-safety strategy on a local scale and provides valuable design criteria.

\section{Introduction}

Approximately $50 \%$ of the world's urbanised areas are located in delta regions (UN Habitat, 2006), characterised by high population numbers and a significant contribution to the economic output of regions and countries. Climate change is expected to lead to a rise in sea levels (Pachauri and Reisinger, 2007) and, as a result, an increasing risk of flooding for many delta regions. Suitable strategies need to be developed, and measures implemented; some of these may find applicability in multiple regions because of similarities between the geographies of different deltas.

The Netherlands has a long history in the development of watersafety strategies. Government authorities and academics actively engage in the Deltaprogram (Deltacommissie, 2008) to analyse the impact of a rising sea level, increasing fluctuations in river discharges and subsidence on the country. The programme aims to provide solutions that ensure water safety until at least 2100; water safety in this context is concerned with limiting both the probability and consequences of flooding (Deltacommissie, 2008). The western part of The Netherlands is a highly urbanised region with port cities that are significantly exposed to rising sea levels (UN Habitat, 2008). Within the Deltaprogram, the sub-programme Rhine Estuary-Drechtsteden (DP RD) concentrates on the port cities of Rotterdam and Dordrecht. Located along the estuaries of the Rhine and Meuse rivers, this region requires protection against storm surges from the North Sea and, potentially concurrent, high water discharges from the rivers (Deltacommissie, 2008).
In the sub-programme DP RD, water-safety interventions are defined through four extreme, large-scale strategies - so-called cornerstones (Deltacommissie Rijnmond - Drechtsteden, 2010). These are based on the basic principle that the water level in an area protected by sea and river barriers is reduced, and hence the amount of dyke reinforcements required for protection is minimised. Each of the strategies has a different impact on flooding risks in inner and outer dyke areas, fresh water supply, shipping traffic, nature and spatial quality at both regional and local scales. Until recently, the emphasis in the assessment of the strategies was on water safety, fresh water supply, nature and economic activity; little attention was paid to the concept of spatial quality, which can be summarised as a combination of three qualitative parameters: utility, attractiveness and robustness (Ruimtexmilieu.nl, 2012).

Improved spatial quality is deemed an important factor for the solution of social-economic problems (Ritsema et al., 2006); the latter frequently occur in the Rhine Estuary-Drechtsteden area, where commercial activity in old sections of its ports is in decline. The city of Rotterdam, in the centre of this vulnerable region, is preparing for urban transformation and strives to strengthen its image as a water city (Gemeente Rotterdam, 2007); improving spatial quality is an important aspect of its plans.

In a study that identifies and quantifies the (dis)advantages of the four strategies (Jeuken et al., 2011), local-scale spatial quality was determined to be an important assessment criterion. However, the effects on spatial quality are not easily 
quantifiable. For conceptual water-safety strategies that are defined on a national and regional scale, much uncertainty remains about suitable measures that can be taken on a local scale. A clear need for qualitative analysis of the effects on nature and spatial quality arises, and hence the need for a methodology for the analysis of spatial effects at a local scale.

Several methods exist for the evaluation of spatial quality. One approach uses a check list or questionnaire that contains qualitative criteria - an example is the so-called Habiforummatrix (Hooimeijer et al., 2001); another approach is based on the involvement of a quality team (Sijmons, 2008). The Ruimtelijke Kwaliteits Toets (RKT, spatial quality assessment framework) is a hybrid of these two approaches and was developed and utilised as part of the Dutch 'Ruimte voor de rivier' programme in 2006 (Bos et al., 2004). In this method, the spatial quality of concrete design proposals for flood risk interventions in a regional landscape is evaluated by an expert team, using a set of criteria that is based on the description of spatial quality as a combination of utility, attractiveness and robustness.

Checklists or questionnaires with qualitative criteria are considered incapable of grasping all subjective aspects of spatial quality (Sijmons, 2008); on the other hand, expert panels are not always verifiable. The RKT is found to be usable (Ruimte voor de rivier, 2006). However, the criteria included in this methodology can be hard to interpret and irrelevant in a particular context - the criteria have been defined towards a rural rather than urban setting, with regional scales and shortterm design proposals in mind. It was advised to continue development of the set of criteria and to use them as guidelines rather than as a formal set of questions to be answered.

In order to meet the need for a suitable methodology for use in the sub-programme Rhine Estuary-Drechtsteden, the research presented in this paper describes an attempt to extend the existing hybrid methodology of the RKT. The goal is to design a methodology that allows the estimation of the impact on spatial quality of conceptual large-scale regional water-safety strategies rather than design proposals, at a local rather than a regional scale and in a more complex urban as opposed to rural context. The proposed methodology is subsequently used to analyse the impact of the four regional water-safety strategies (cornerstones) defined for the Rijnmond-Drechtsteden area.

\section{Materials and methods}

Water-safety interventions for the protection of the RijnmondDrechtsteden region are defined through four extreme, largescale strategies - so-called cornerstones (Deltacommissie Rijnmond - Drechtsteden, 2010). These are all based on the basic principle that the water level in an area protected by sea and river barriers is reduced, and hence the amount of dyke reinforcements necessary for protection is minimised. The choice of water-safety strategy at a large, regional scale has an impact on water levels throughout that region. Depending on the strategy chosen, additional water-safety interventions are required at a local scale, which affect spatial quality.

The four cornerstones (strategies) are listed below.

Improved closable - A continuation of present-day Dutch water-safety strategy. The safety-level of the

Maeslantkering, a large, flexible, storm surge barrier near Rotterdam, is increased; peaks in high water-levels in the region are reduced, with some dyke reinforcements remaining necessary.

- Closable but open - An extension of the current strategy with flexible river barriers to prevent flooding in case high river discharges coincide with a storm surge from the North Sea. High-water levels in the protected area can be kept at an acceptable level and require relatively few local-scale interventions. Water levels upstream of the barriers rise, resulting in the need for additional water-safety measures in areas beyond the barriers.

- Closed - Eliminates the risk of failure inherent in flexible barriers of the closable but open type by using closed dams and locks. Water levels in the urban area within the barrier system can be fully controlled and lowered.

Open - Restores the naturally open connections between the North Sea, rivers and waterways in the Rhine EstuaryDrechtsteden; in case of a storm surge, any existing dams or flexible barriers are no longer used. This scenario leads to more extreme water-level fluctuations throughout the area and requires the strongest local-scale interventions.

Several different local-scale location types that frequently occur throughout the area were identified; together, these are representative for the spatial composition in this complex and diverse region. The location types are: a levee in a rural setting adjacent to the Haringvliet river, with buildings located behind it; a levee with buildings on top of it; a levee with historical buildings behind it; a levee as part of an urban river front; an outer dyke urban transformation zone; an outer dyke area with historical buildings; and an outer dyke area with buildings approximately $20-30$ years old.

For each of the cornerstones, the effects on spatial quality at a local scale have been assessed in two work group sessions with an expert panel of the following composition: two urban designers, one landscape architect, one architect and one ecologist. Involving two urban designers allows the evaluation of judgements and arguments for consistency; it may also give an indication of the level of subjectivity involved. Involving experts from multiple disciplines increases the chance of identifying aspects that are relevant to the evaluation of spatial quality 
(Janssen-Jansen et al., 2009). All of the experts were familiar, at least to some extent, with the locations used in the sessions.

The selected locations have been visualised as cross-sections in a consistent and neutral fashion (Figure 1). Each cross-section includes projected water levels, based on a probability of a 1 in 100 and a 1 in 1000 years occurrence, possibly varying for each cornerstone (Huizinga, 2011). Based on the water levels occurring at a specific location as a result of the regional-scale strategy, choices can be made regarding local-scale watersafety interventions.

In the first work group session, the expert panel identified suitable local-scale water-safety interventions for each location and water level. A civil engineer assisted the panel with this selection process. The selection was limited to conventional, widely accepted interventions, such as the construction of new or reinforcement of existing levees, quays, dams, locks (Waterschap Hollandsche Delta, 2012), land elevations and flood-proof buildings (Figure 2). Water safety, technical and spatial quality aspects were taken into account, while assuming the continued validity of current water-safety norms.
In addition to establishing suitable local-scale interventions, one of the interventions was evaluated using the existing RKT in order to identify specific issues in the existing methodology and to be able to design an improved model for use in the second work group session. The expert panel found the criteria to be unsuitable for the evaluation of spatial quality in an urban environment. In addition, the criteria were considered unclear and difficult to interpret, the structure of the questionnaire was considered too rigid, and some criteria were suggestive with regard to interpretation of the qualitative aspect.

In order to improve applicability of the methodology, both the working principle of the questionnaire and the formulation of the criteria were changed. Whereas the original RKT questionnaire assumes all criteria are evaluated and rated for any given location, the adjusted methodology provides more flexibility to the expert panel in describing their judgement, in choosing criteria deemed relevant and to allow for inclusion of specific criteria that were not foreseen beforehand. Criteria not relevant for a location need not be evaluated. For example, some criteria may be relevant in an urban setting, while others are relevant in a rural context.

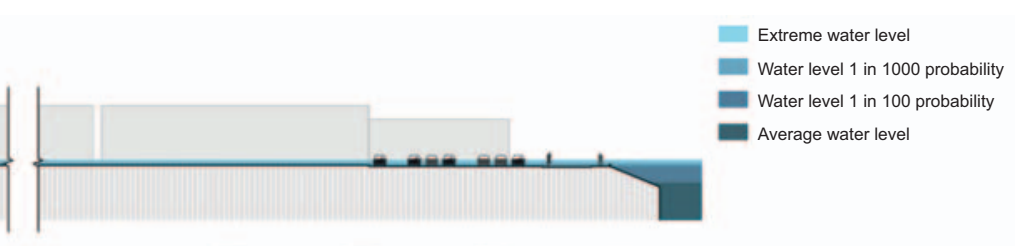

Reference 2015

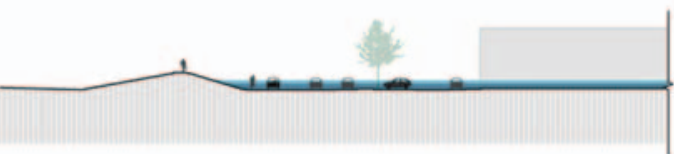

Improved closable 2100

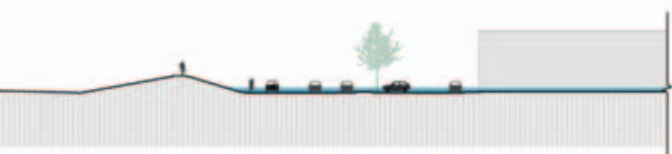

Closable but open 2100
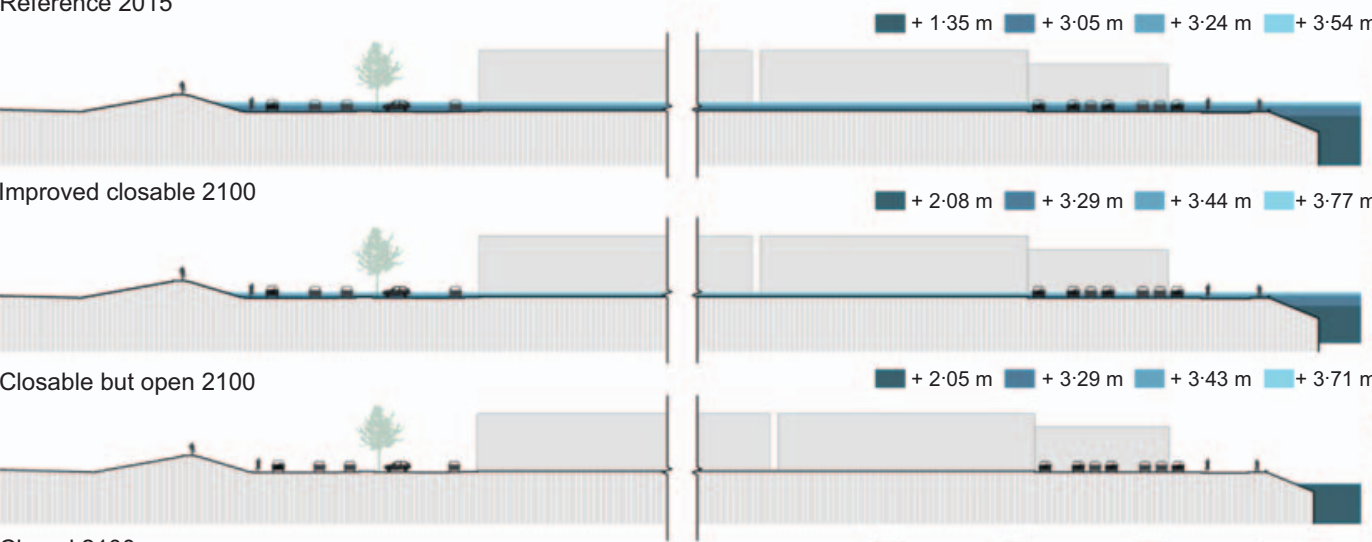

$\square+2.08 \mathrm{~m}=+3.29 \mathrm{~m}=+3.44 \mathrm{~m}+3.77 \mathrm{~m}$
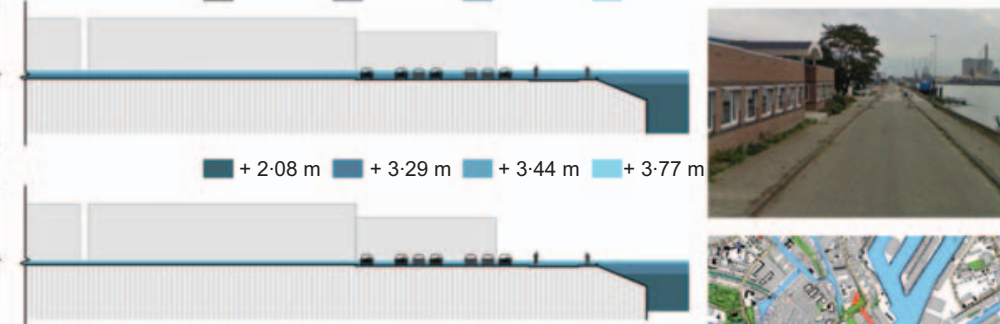

Closed 2100
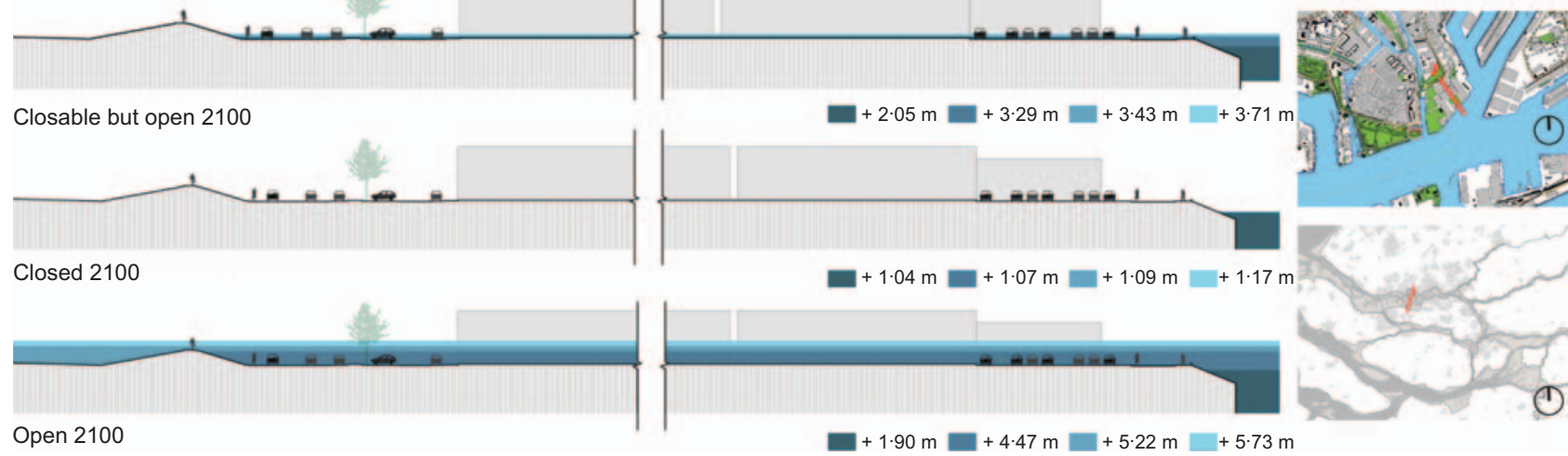

Figure 1. Cross-sections of the urban transformation zone location, showing the current water levels (2015 reference) and the projected water levels for the different cornerstones in 2100 

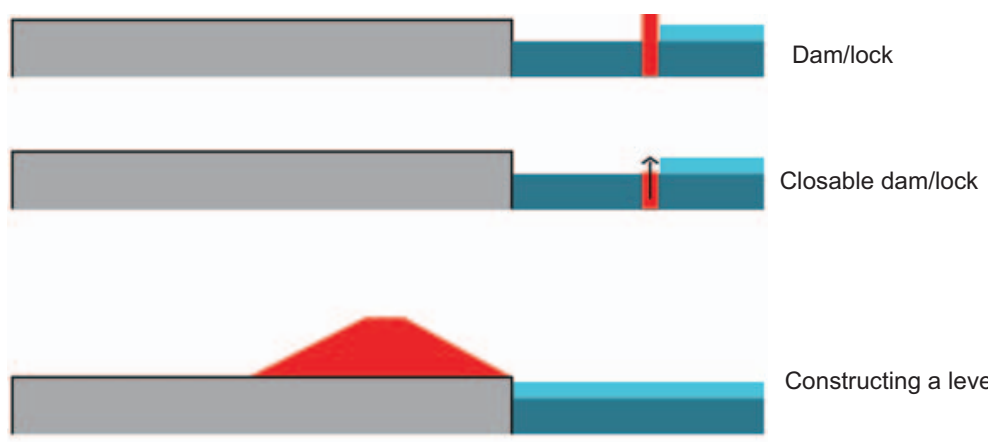

Constructing a levee

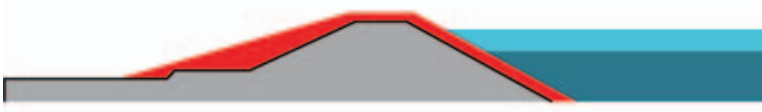

Super levee

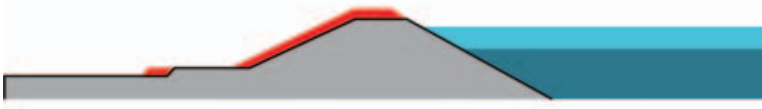

Levee elevation

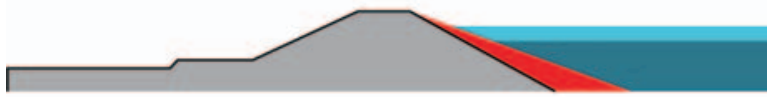

Slope reconstruction

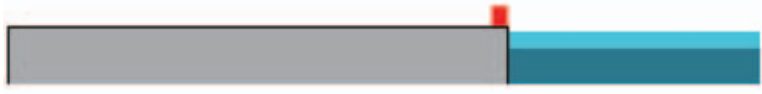

Quay wall

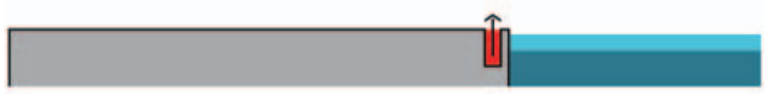

Movable quay wall

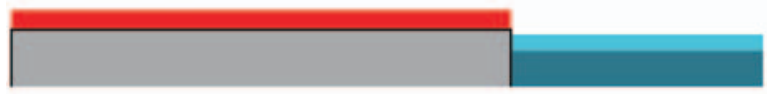

Land elevation

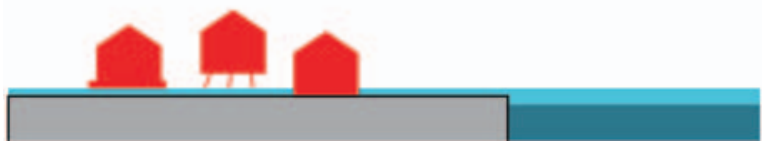

Flood-proof buildings

Figure 2. Conventional, widely accepted water-safety interventions to be selected for the locations based on the water levels occurring

The set of criteria was modified and extended based on literature (Gehl et al., 2006; Hooimeijer et al., 2001) and in consultation with the expert panel. Some of the original RKT criteria were removed or combined, such as economic vitality and urban aspects. Other RKT criteria were reused: functioning as residential, commercial, recreational or public space; accessibility and routing; ecological functioning; maintainability; identity of the location/surroundings; recognition of structures; cultural recognition; spatial recognition; diversity/ alteration; uniqueness; logic of spatial arrangement; image; water-safety experience; attractiveness; intervention versus location scale; relation to the water; reversibility; development opportunities; multifunctional space utilisation; robustness; flexibility and durability. Ten new criteria were added: future value; feasibility of gradual development; experience value; colour palette; uniqueness; the logic of the spatial arrangement; 
lines of sight; identity; scale of the local intervention; and seasonal attractiveness.

In the second expert panel meeting, the local-scale water-safety interventions were assessed for their impact on spatial quality using the improved methodology. The current situation was described using a map of the area, a neutral three-dimensional sketch (Figure 3) and impressions from Google Street View. Differences between the current situation and the situation based on the combination of regional (cornerstone) and local intervention were described. Local interventions were visualised in the cross-sections of the locations.

The members of the expert panel had the opportunity to share and explain their choice of relevant criteria and subsequent evaluation before giving a final judgement. This allowed learning from others' arguments and, possibly, revising choices and judgements. At the end of the evaluation of each location, the expert panel was asked to reach consensus on the effects of each local water-safety intervention (Figure 4).

In a follow-up workshop to the two expert panel work group sessions, a group of graduate students from Delft University of Technology, Faculty of Architecture, investigated which criteria had negative scores; an attempt was made to neutralise the negative effects by optimising designs.

\section{Results and discussion}

The methodology for the assessment of spatial quality was developed throughout the research period and focused on applicability in an urban setting. The list with criteria was modified to reflect usage in an urban context. Criteria frequently mentioned as relevant to the Rijnmond-Drechtsteden area were: direct 'view' relation with water, opportunities for new water living environments, logic of an intervention, and the scale of an intervention versus the scale of the surroundings. The new visual tools offered in the two work group sessions were valuable additions.

Generally, new or additional water-safety interventions are judged as positive in areas that require restructuring; this offers chances for the creation of distinguishable and unique waterrelated environments. During the assessments the identity of the open water and the view towards it proved to be important criteria for spatial quality of the locations. For the cornerstones that resulted in water-safety interventions up to approximately $0.7-1.0 \mathrm{~m}$ in height in existing built areas, that is 'Closable but open' and 'Improved closable', these criteria frequently received a positive rating from the panel members. In the case of the extreme water levels that occur outside the barriers for the cornerstones 'Closable but open' and 'Closed', the reinforcement of existing levees, which have a strong relationship with the built environment, is required. Those reinforcements received a negative assessment, as the scale of the intervention does not seem to fit in well with the human scale of the built environment. However, large-scale interventions at a local scale did not always receive a negative evaluation; in the case of the 'rugged' levees along the Haringvliet, reinforcements of the levees deemed necessary for the 'Open' cornerstone were of the same scale and character as the surrounding landscape and received a positive assessment. The drastic interventions required in the case of the 'Open' cornerstone in the built area received negative feedback from the expert panel.

During the work group sessions, the two urban designers provided different judgements, demonstrating the challenges of obtaining reliable, consistent and objective results that are independent of individual, subjective opinions.

As the criteria to measure spatial quality became starting points for the design assignment, the students succeeded in making designs that had a better score with respect to spatial quality. It may be worthwhile to add such a design optimisation approach to the assessment framework in a next phase; this 'research by design' may help to identify which negative aspects of an intervention can be neutralised by integration into a design, and which negative aspects are impossible to mitigate and therefore unacceptable.

\section{Conclusion}

A methodology for spatial quality assessment was presented that builds on the RKT - a similar and existing methodology that is applicable for assessing the impact of concrete design proposals on spatial quality in a landscape setting, at a regional scale. The revised methodology has been changed to be suitable for assessing the impact of large-scale water-safety interventions on local-scale spatial quality in an urban delta region. Where existing methods require concrete design proposals for evaluation, the new approach allows the evaluation of largescale water-safety interventions in an earlier stage of the development.

Supported by positive results achieved with this method, it is deemed suitable for use in follow-up phases in the Deltaprogram. In order to improve its accuracy and applicability, it is recommended to evaluate a larger number of crosssections in any future research programmes. A map should be made that shows the occurrence of specific types of locations throughout the region so as to clarify what the locations and cross-sections actually represent. Locations should be compared during the evaluation of cornerstones; a decrease in spatial quality may be a bigger problem in one location than in another.

The methodology is well suited for application in regions beyond The Netherlands. However, several boundary conditions need to 


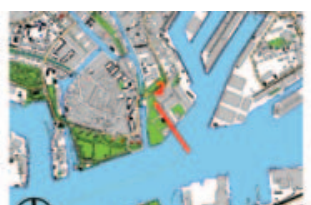

(1) 910
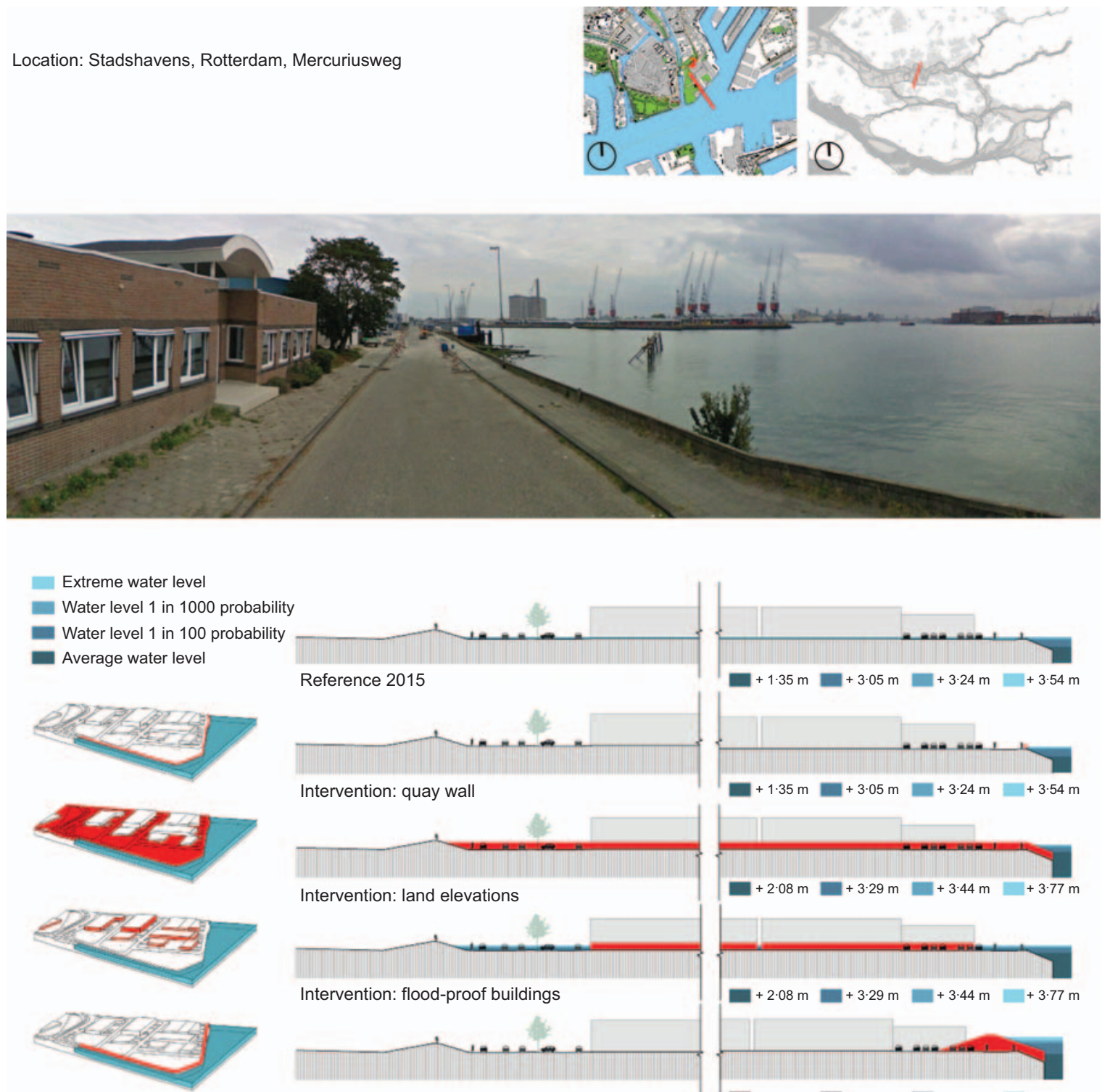

Reference 2015

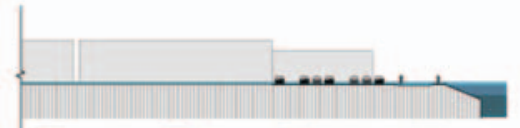

$+1.35 \mathrm{~m}=+3.05 \mathrm{~m} \quad+3.24 \mathrm{~m} \quad+3.54 \mathrm{~m}$

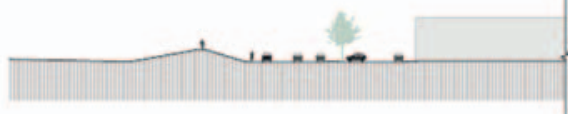

Intervention: quay wall

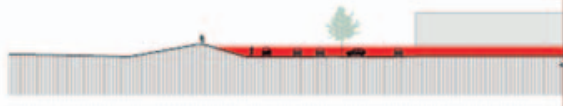

Intervention: land elevations

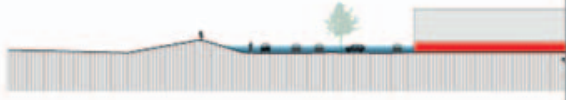

Intervention: flood-proof buildings

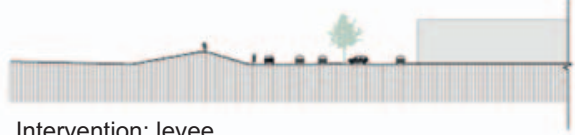

Intervention: levee

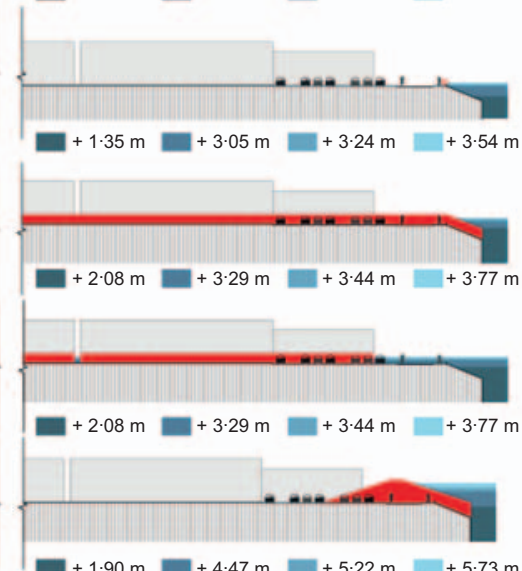

W $1.90 \mathrm{~m} \quad+4.47 \mathrm{~m} \quad+5.22 \mathrm{~m} \quad+5.73 \mathrm{~m}$

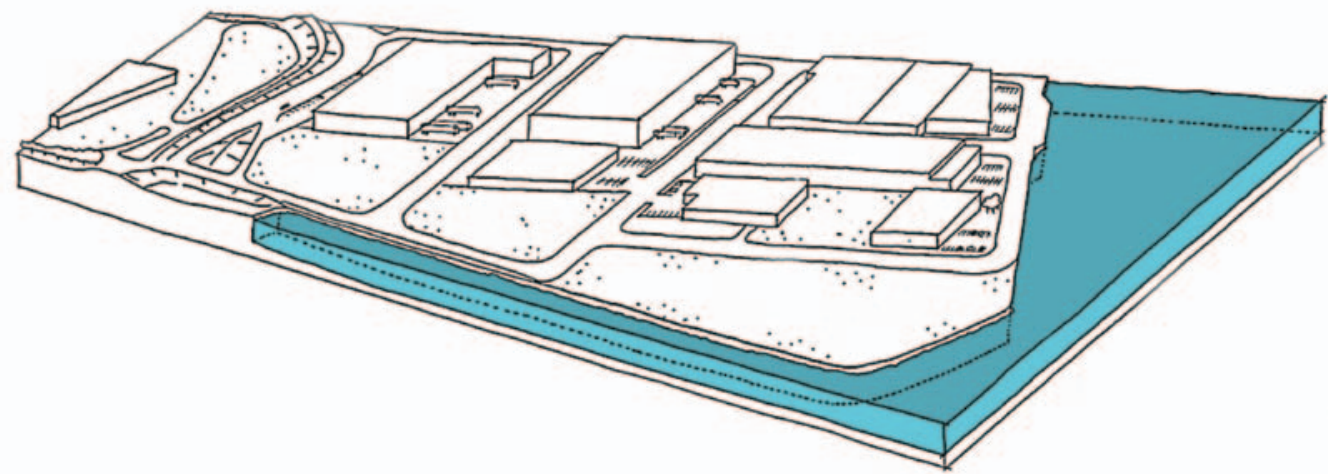

Figure 3. Selected water-safety interventions projected within the location, in this case the outer dyke redevelopment area 


\section{Location Stadshavens, Rotterdam, Mercuriusweg \\ Intervention Constructing a levee}

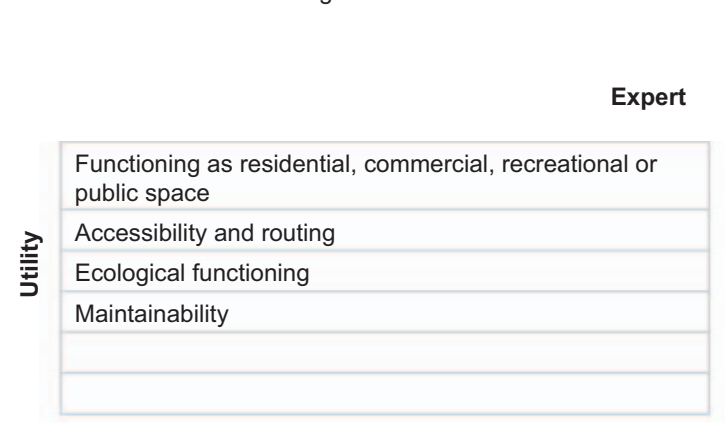

\begin{tabular}{|l|l|}
\hline Identity of the location / surroundings \\
\hline Recognition of structures \\
\hline Cultural recognition \\
\hline Spatial recognition \\
\hline & Diversity / alteration \\
\hline & Uniqueness \\
\hline Attractiveness \\
\hline Intervention scale versus location scale \\
\hline Relation to the water \\
\hline
\end{tabular}

\begin{tabular}{|l|l|}
\hline & Reversibility \\
\hline & Development opportunities \\
\hline \multirow{2}{*}{} & Mulifunctional space utilisation \\
\hline \multirow{5}{*}{} & Robustness \\
\hline \multirow{2}{*}{} & Flexibility \\
\hline \multirow{2}{*}{ Durability } \\
\hline
\end{tabular}

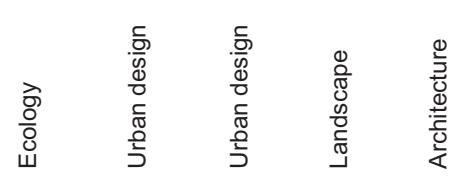
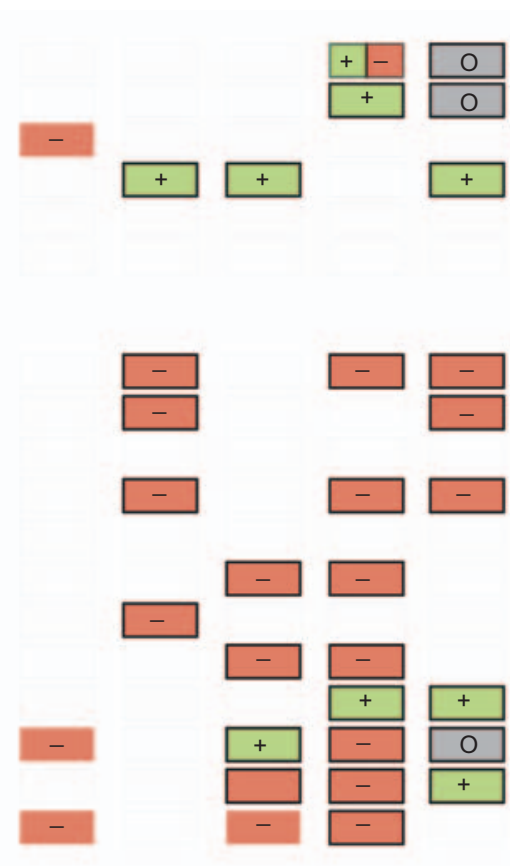

\begin{tabular}{|l|l|l|l|l|l|}
\hline Group assessment & 0 & $0-$ & + & - & - \\
\hline
\end{tabular}

Figure 4. Assessment of the impact of constructing a levee as a water-safety intervention in the outer dyke redevelopment area

be met. Sufficient data are required regarding the expected changes in water levels throughout an area of interest as a result of a specific regional intervention. Considering that international engineering companies are often involved in large-scale water-safety interventions, the required knowledge may well be available in developed as well as less developed countries. In addition, the availability of a team of experts that is both familiar with the phenomenon of spatial quality and has sufficient knowledge of a region is key to successful application of this method. A well-balanced selection of 
experts will contribute to the outcome, as will the availability of knowledge from domains such as civil engineering.

The results from the assessment of spatial quality may differ between regions as the methodology contains both objective and subjective qualitative criteria. In other deltas, the same criteria might be assessed or interpreted differently, since the assessment is subject to location, zeitgeist and culture (JanssenJansen et al., 2009).

\section{REFERENCES}

Bos M, Lagendijk O and van Beusekom E (2004) Ruimtelijke Kwaliteit in de MER Ruimte voor de Rivieren: Beoordelingskader (BOK), Vragenlijst effectbepaling alternatieven en regiomodules. Ruimte voor de Rivier (Room for the River), Utrecht, The Netherlands, p. 3 (in Dutch).

Deltacommissie (2008) Working Together with Water, A Living Land Builds for its Future: Findings of the Deltacommissie 2008. Deltacommissie (Deltacommittee), The Hague, The Netherlands (in Dutch).

Deltacommissie Rijnmond-Drechtsteden (2010) Samenvatting Plan van Aanpak. Deltacommissie (Deltacommittee), The Hague, The Netherlands (in Dutch).

Gehl J, Gemzøe L, Kirknæs S and Sternhagen Søndergaard B (2006) New City Life. The Danish Architectural Press, Copenhagen, Denmark, pp. 106-107.

Gemeente Rotterdam (2007) Waterschap Hollandse Delta, Hoogheemradschap van Schieland en de Krimpenerwaard, Hoogheemraadschap van Delfland, Waterplan 2 Rotterdam, Werken aan water voor een aantrekkelijke stad. Gemeente Rotterdam, Rotterdam, The Netherlands (in Dutch).

Hooimeijer P, Kroon H and Luttik J (2001) Kwaliteit in Meervoud: Conceptualisering en Operationalisering van Ruimtelijke Kwaliteit voor Meervoudig Ruimtegebruik (Operationalisation of Spatial Quality for Multiple Land Use). Habiforum, Raad voor Ruimtelijk, milieu en natuuronderzoek, Innovatienetwerk Groene ruimte Agrocluster (Council for Planning, Environment and Nature Research, Innovation Network Green Space and Agricultural Systems), Gouda, The Netherlands (in Dutch).

Huizinga J (2011) Eerste Generatie Oplossingsrichtingen voor Klimaatadaptatie in de Regio Rijnmond-Drechtsteden Deelrapport: Effecten op Buitendijkse Overstromingsrisico's. Knowledge for Climate, HKV lijn in water, Delft, The Netherlands (in Dutch).

Janssen-Jansen L, Klijn EH and Opdam P (2009) Ruimtelijke Kwaliteit in Gebiedsontwikkeling. Habiforum, Gouda, The Netherlands, pp. 7, 19 (in Dutch).

Jeuken A, Kind J and Gauderis J (2011) Eerste Generatie Oplossingsrichtingen voor Klimaatadaptatie in de regio Rijnmond-Drechtsteden Deelrapport: Syntheserapport:
Verkenning van Kosten en Baten. Delta Programme, Deltares, The Netherlands, report 1204302-000 (in Dutch). Pachauri RK and Reisinger A (2007) Climate Change. IPPC Intergovernmental Panel on Climate Change, Geneva, Switzerland, Synthesis Report.

Ritsema van Eck J, Verkade E, Ossokina L et al. (2006) Welvaart en Leefomgeving: een Scenariostudie voor Nederland in 2040. Planbureauvoor de Leefomgeving (Netherlands Environmental Assessment Agency), The Hague, The Netherlands, Ch. 11, pp. 495-499 (in Dutch).

Ruimte voor de rivier (2006) Evaluatie Ruimtelijke Kwalitietstoets. Ruimte voor de Rivier (Room for the River), Utrecht, The Netherlands (in Dutch).

Ruimtexmilieu.nl (2012) Handreiking voor Duurzame Gebiedsontwikkeling (in Dutch). See http://www. ruimtexmilieu.nl/index.php?nID=229 (accessed 18/05/ 2012).

Sijmons D (2008) Werken met Kwaliteitsteams. Kwaliteitsteam, Ruimte voor de Rivier (Quality assurance team, Room for the River), Utrecht, The Netherlands (in Dutch).

UN Habitat (2006) State of the World's Cities 2006/7: The Millennium Development Goals and Urban Sustainability: 30 Years of Shaping the Habitat Agenda. UN Habitat, Nairobi, Kenya.

UN Habitat (2008) State of the World's Cities 2008/2009: Harmonious Cities. UN Habitat, Nairobi, Kenya.

Waterschap Hollandse Delta (2012) Waterschap Hollandse Delta, oplossingsrichtingen zwakke punten (in Dutch). See http:// www.wshd.nl/dijkversterkingsprogramma/beheer/ hoe_wordt_een_dijk (accessed 18/05/2012).

\section{WHAT DO YOU THINK?}

To discuss this paper, please email up to 500 words to the editor at journals@ice.org.uk. Your contribution will be forwarded to the author(s) for a reply and, if considered appropriate by the editorial panel, will be published as discussion in a future issue of the journal.

Proceedings journals rely entirely on contributions sent in by civil engineering professionals, academics and students. Papers should be 2000-5000 words long (briefing papers should be 1000-2000 words long), with adequate illustrations and references. You can submit your paper online via www.icevirtuallibrary.com/content/journals, where you will also find detailed author guidelines. 